\title{
CORONA Satellite Photography and Ancient Road Networks: A Northern Mesopotamian Case Study
}

\author{
Jason $\mathrm{Ur}^{*}$
}

Middle-eastern archaeologists are winning new information from declassified military photographs taken 25 years ago. This study shows how pictures of north-eastern Syria are revealing the routeways, and by inference the agricultural systems of Mesopotamia in the early Bronze Age.

Keywords: satellite photography, CORONA, Early Bronze Age, Mesopotamia, routeways

\section{Introduction}

Landscape archaeology has emphasised the role of the entire landscape in ancient life, rather than putting an exclusive focus on those loci of intensive behaviour we call "sites." The broader area of interest requires a corresponding reduction in intensity, the difference between digging a $100 \mathrm{~m}^{2}$ trench and surveying a $200 \mathrm{~km}^{2}$ region. In order to study entire regions efficiently, landscape archaeologists have normally turned to remote sensing data sources. In the Middle East, aerial photographs have been difficult to obtain, so these sources have generally been limited to low resolution SPOT and LANDSAT imagery, which are sufficient for geomorphological studies but too coarse to detect most archaeological landscape features. Archaeologists working in the Middle East are now beginning to take advantage of a newly available resource, the declassified CORONA satellite program, which combines the large coverage of the modern low resolution satellites with the high resolution of aerial photography. In this case study, I have used CORONA photographs to identify and map ancient road systems in north-eastern Syria (Figure 1).

\section{Hollow ways}

Hollow ways, also called linear hollows or sunken lanes, are broad and shallow linear depressions in the landscape, thought to be formed by the continuous passage of human and animal traffic (Taylor 1979, Tsoar \& Yekutieli 1993, Wilkinson 1993). They occur on the dry farming plains of northern Mesopotamia and elsewhere in the Middle East, and are generally 60-120 m wide and 0.50-1.5 m deep. In spite of their size, these hollow ways can be difficult to detect on the ground (Figure 2). The largest ones may be visible under certain light conditions and oblique angles, and in the dry season, a slightly thicker scatter of weeds

*University of Chicago Oriental Institute, 1155 E. 58th St., Chicago, IL 60637 (j-ur@uchicago.edu)

Received 11 July 2002; Revised 16 January 2003. 


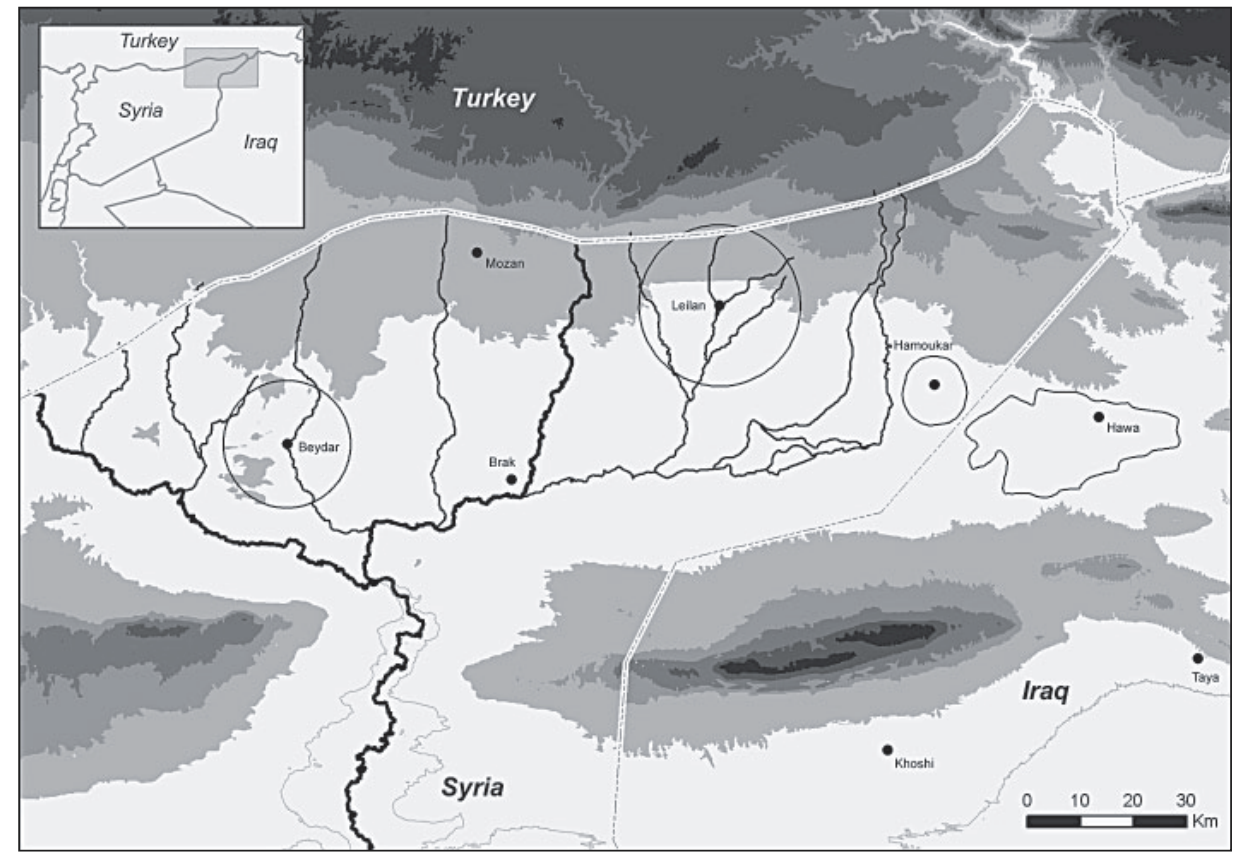

Figure 1. The Upper Khabur basin, with major urban sites of the $3 r d$ millennium BC and intensive survey areas discussed.

may mark the position of the trough. From the air, however, hollow ways are immediately visible. In northern Mesopotamia, their visibility can be explained differently in different seasons. In the summer and autumn they are detectable as soil marks because their troughs retain moisture and promote weed growth. In the spring, these moistureretaining properties encourage denser growth of grass crops, producing distinctive crop marks.

Hollow ways in northern Mesopotamia were initially studied by Van Liere and Lauffray in the Upper Khabur basin (Van Liere and Lauffray 1954-55, Van Liere 1963). Using low level aerial photographs, they mapped out a basin-wide

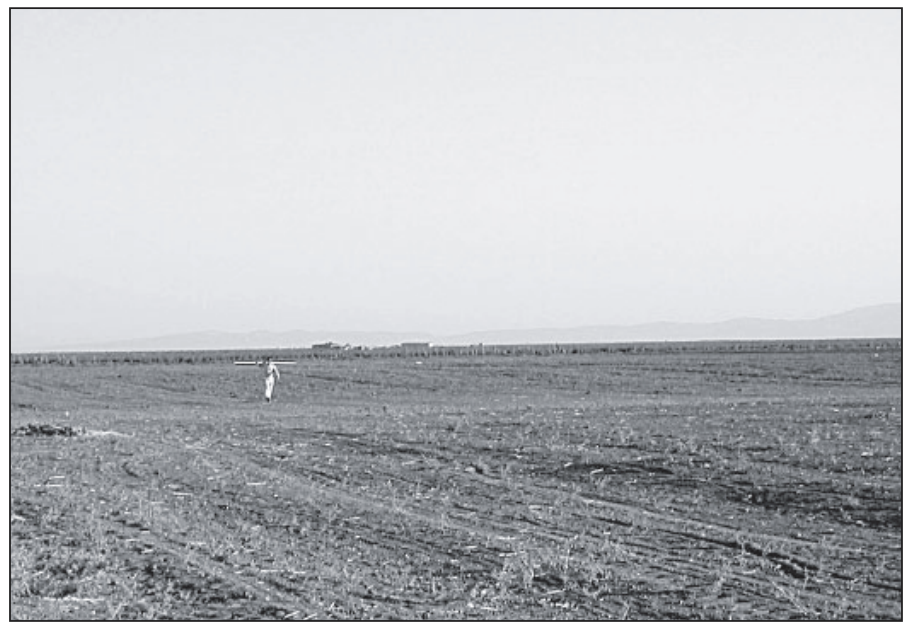

Figure 2. Oblique view of a $100 \mathrm{~m}$ wide hollow way SW of Tell Hamoukar. pattern of small radial systems around Bronze Age tell sites and a second narrower group associated with Byzantine sites. They concluded from these small non-integrated systems that the Bronze Age landscape consisted of systems of economically independent agricultural towns and their satellite-settlements (Van Liere and Lauffray 1954-55: 146). 


\section{Jason $U r$}

More recently, T.J. Wilkinson has mapped hollow ways in Syria, south-eastern Turkey, and northern Iraq, based on aerial photography and topographic maps (Wilkinson 1993, Wilkinson and Tucker 1995). Similar radial systems were found, but the tendency for many hollow ways to terminate without connecting with another site led Wilkinson to conclude that these roads also were used for movement to and from fields and pasture, and that animal traffic was also involved in their formation. Furthermore, a small group of interregional hollow ways suggested that these radial systems were more integrated than Van Liere and Lauffray supposed. Finally, the modern site collection methodology applied demonstrated the strong association of these features with sites of the 3rd Millennium BC, although their sporadic use in other periods could not be excluded.

An alternative interpretation has seen hollow ways not as roads but as deliberately excavated channels in order to "harvest" runoff rainfall from the immediate hinterland of 3rd Millennium sites into depressed areas near sites (McClellan and Porter 1995, McClellan et al. 2000). Villagers in the Hamoukar area call hollow ways "wadis" in recognition of their unintended hydraulic function; they also claim that none of these features has been a track since the area was resettled in the 1950's. However, Wilkinson has demonstrated that these hollow ways run across watersheds, and that they do not have the upcast that would be expected from the necessary maintenance of canal features (Wilkinson and Tucker 1995: 26-27).

The antiquity of hollow ways has been questioned by several researchers who suggest that alluvial aggradation within the basin would have covered all traces of the 3rd Millennium BC land surface; the linear depressions must therefore be modern (Weiss and Courty 1994, Weiss 1997). It is certainly true that the Upper Khabur basin landscape has evolved since the main period of hollow way formation in the Early Bronze Age (EBA); aggradation of alluvial sediments approaches $4 \mathrm{~m}$ in depth in the wadi floodplains (Courty 1994). However, the basin is not topographically flat, and alluvial aggradation is far from uniform. The wadi floodplains, where most aggradation occurs, are generally less than $100 \mathrm{~m}$ wide (Courty 1994: 30). The watersheds and associated slopes between the wadi floodplains have remained relatively stable or even subject to erosion, preserving late Neolithic sites up to $1 \mathrm{~m}$ in height (Wilkinson 2000); it is there that hollow ways are most visible. Furthermore, it is important to bear in mind that hollow ways are the traces of ancient roads, not the roads themselves, which have been transformed by erosion and aggradation. It is only the surface manifestation of the underlying feature, in the form of crop and soil marks, that is available for surface study.

\section{CORONA imagery}

Given the difficulty of identifying and mapping hollow ways from the ground, it is not surprising that all previous studies have made use of remote sensing data, usually aerial photographs. Van Liere and Lauffray based their maps on over 10,000 low level aerial photographs. Wilkinson's maps were also based on aerial photographs and LANDSAT imagery, in association with high resolution topographic data. McClellan's study utilised SPOT imagery.

In recent years, satellite imagery has become readily available and affordable to archaeologists, particularly SPOT and LANDSAT, but it has proven to be less useful for identification of most landscape features due to its relatively low resolution (Kouchoukos 2002). While geomorphological features such as rivers and modern land use are easily recognisable on such 
imagery, most archaeological phenomena are too small to register on them.

Recently, however, a satellite data source has become available which combines the high resolution and legibility of traditional aerial photographs with the greater aerial coverage of satellite imagery. The CORONA satellite program was the first American intelligence satellite program, in operation from 1959 to 1972 (Day et al. 1998). Newer satellite systems have rendered CORONA obsolete for intelligence purposes, but their potential value for scholarly research led to their declassification in 1995. A total of 800,000 images is now available for previewing and ordering over the internet. While age is normally considered a disadvantage in regard to satellite imagery for intelligence purposes, this is not the case for archaeology: CORONA photographs preserve the landscape of the late 1960's and early 1970's, a time at the very beginning of the expansion of towns and intensive mechanical agriculture in the Upper Khabur basin. As a result, we have a record of many subtle landscape features which have been subsequently damaged or destroyed.

Archaeologists working in the Near East have begun to take advantage of CORONA photographs. David Kennedy has examined several Turkish sites (Kennedy 1998), and a recent survey project in the Orontes Valley has used them to identify sites, relict field systems, and ancient canals (Phillip et al. 2002). CORONA photographs have aided geomorphological study of the complex hinterland of the Bronze Age site of Tell Brak (Wilkinson et al. 2001).

In the Upper Khabur basin, CORONA photographs have been particularly useful in identifying ancient sites and landscape features (Figure 3). Habitation sites in this region are composed of layers of eroded mud brick and associated layers of anthropogenic debris, sometimes formed over thousands of years of occupation. During most of the year, these ancient sites appear as lighter spots against the basin's natural reddish brown calcareous soils (calcic xerosols). This higher reflectance can be attributed to the better drainage of sites' anthropogenic soils and poorly developed soil structure; the off-site terrain's developed soil structure, texture, and mineralogy retain moisture much more efficiently.

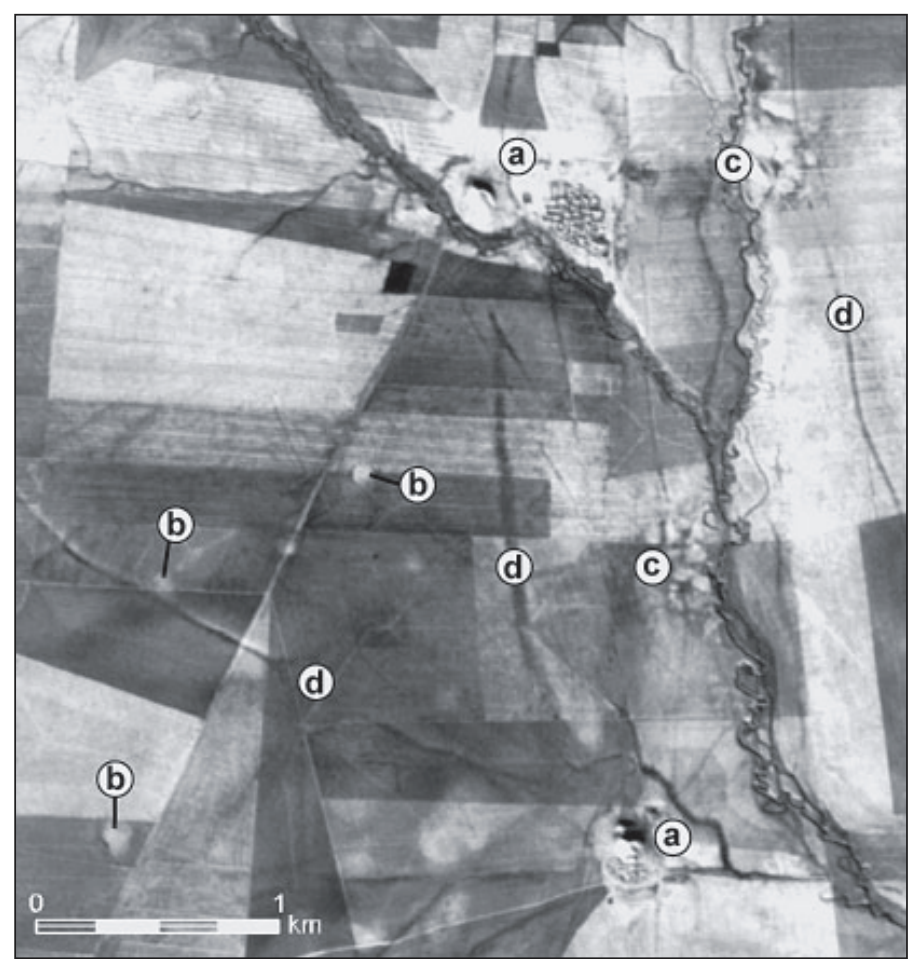

Figure 3. Dec. 1967 CORONA photograph (DS1102-1025DA012). a. High mounded tell sites; $b$. lower $(2-3 \mathrm{~m})$ mounds; c. complex sites of multiple mounds and brick extraction pits; $d$. hollow ways. 


\section{Jason $U r$}

On the photographs, most hollow ways have a distinctive signature which can be easily distinguished from modern roads and natural wadi courses. The moist soils in the trough are less reflective, producing a broad dark line on the image. The edges of the hollow way slope down from the surrounding land surface to the trough. This increased gradient (relative to the flatter surrounding surface) promotes drainage and thus light reflectance; therefore the dark trough of the hollow way often has two light margins on either site of it. In some cases, these margins are absent. Ground observation has demonstrated that these margin-less hollow ways are in fact not depressed. When these hollow ways are related to the surrounding terrain, they almost always run perpendicular to the natural slope of the landscape, while hollow ways with light margins run parallel to the slope. It appears that the former type acts to capture eroding sediments, while the latter type probably focuses and increases runoff (Wilkinson 1993: 552-54).

The infilled hollow ways still appear dark on the photographs because the buried compacted road surface still impedes the movement of moisture. The distinctive signatures of hollow ways differ from those of modern tracks, in that they are much broader. Even the largest asphalt roads in the region rarely approach a width of greater than $10 \mathrm{~m}$, and the most typical dirt tracks are generally 3-4 m wide. Gravelled roads and recent dirt tracks are highly disturbed by recent movement and are also whitish in most seasons. Hollow ways and wadis

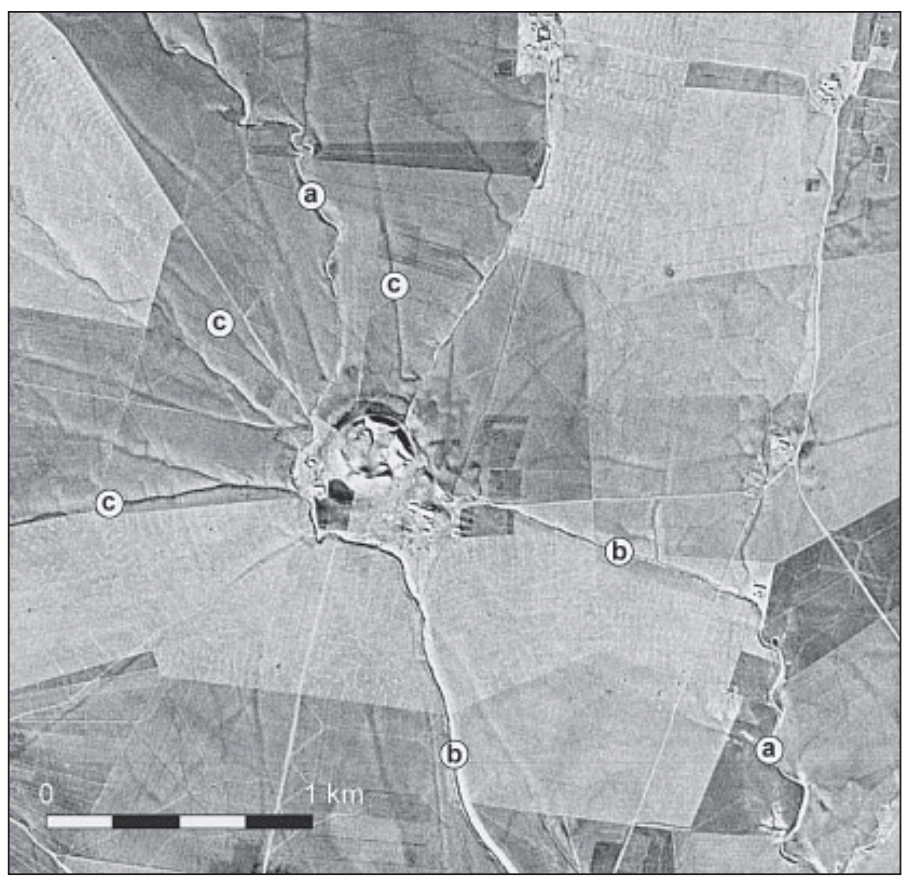

Figure 4. Nov. 1968 CORONA photograph (DS1105-1025DF058) of Tell Aswad Foqani. a. Natural meandering wadi courses; $b$. linear hollow ways which have "captured" wadi flow; c. hollow ways which have been deepened by runoff erosion.

have superficial similarities in that they are both sunken beneath the surrounding terrain and both serve to channel runoff or even redirect the natural hydrology (Figure 4). However, wadis have a characteristic sinuous shape, whereas hollow ways are typically linear.

\section{GIS-based mapping of hollow ways}

For the Upper Khabur basin and surrounding areas of Northern Mesopotamia, the Center for the Archaeology of the Middle Eastern Landscape (CAMEL) of the University of Chicago Oriental Institute has begun to remap hollow ways from CORONA imagery. Using Geographical Information Systems (GIS) software, these features are being spatially integrated 
with geomorphological and environmental data (topography, geology, rainfall) as well as settlement data from archaeological survey. Our GIS database combines the results of intensive surveys in the Iraqi North Jazira (Wilkinson and Tucker 1995), the Tell Beydar Survey (TBS; Wilkinson 2000), and the Tell Hamoukar Survey (THS; Ur 2002) with site and landscape data extracted from CORONA photographs and other remote sensing data sources. When completed, this database will facilitate the diachronic analysis of settlement patterns, landscape features, and the evolving relationship between them.

The hollow way component of this multi-layered database is being constructed by means of the scanning, rectification, and vectorisation of CORONA photographs. Because CORONA photographs are not available as digital products, they must be scanned and warped into a geographic co-ordinate system. Our methods are relatively simple: the photographic negative is scanned at a resolution of 1600 pixels per inch (ppi); the resulting digital image is imported into the ENVI 3.5 image processing software package, where it is transformed into a geographically corrected image by reference to ortho-rectified SPOT imagery. The warped images are then projected into the UTM co-ordinate system [National Grid] and imported as a layer in the ArcGIS 8.2 software package, where hollow ways and other archaeological and modern features can be traced into separate vector layers (for a more elaborate method, see Phillip et al. 2002)

At the current stage of the project, we have identified 1,192 hollow ways for a total of $1,712.9 \mathrm{~km}$ of ancient roads. Our mapping has focused initially on the areas of the plain encompassed by and immediately beyond the areas of intensive survey. In the western basin, this includes the area between Tell Beydar, Chagar Bazar and Tell Brak; in the eastern basin, our mapping extends from Hamoukar to Tell Leilan.

\section{Dating and morphology}

The initial association of broad hollow ways with Bronze Age tells and narrower hollow ways with Byzantine and Early Islamic sites (Van Liere and Lauffray 1954-55, Wilkinson and Tucker 1995) has been confirmed by ground control in the TBS and THS areas. For example, from the large EBA town of Tell Beydar, a bifurcating hollow way departs from the eastern outer city gate and runs eastward to the 15 ha EBA town of Tell Effendi (TBS 55) along its northern branch, and to the small EBA village of Tell Kaferu (TBS 10) along its southern (Figure 5). Well-developed radial systems exist around most other surveyed EBA sites in the area.

In the THS survey area (Figure 6), a series of broad hollow ways can be associated with a re-entrant contour in the western edge of the 3rd millennium BC lower town, probably the remains of an ancient gate in the city wall or a point of access to the town. While the THS recovered a continuum of hollow way widths, a class of narrower (40-60 m) hollow ways could be distinguished; these were associated with sites of Late Byzantine-Early Islamic date. At a point of intersection between a broad and a narrow hollow way, the relative stratigraphy of these features could be discerned; the trough of the Byzantine-Islamic narrow hollow way clearly cuts into that of the broad EBA hollow way (Figure 7). 


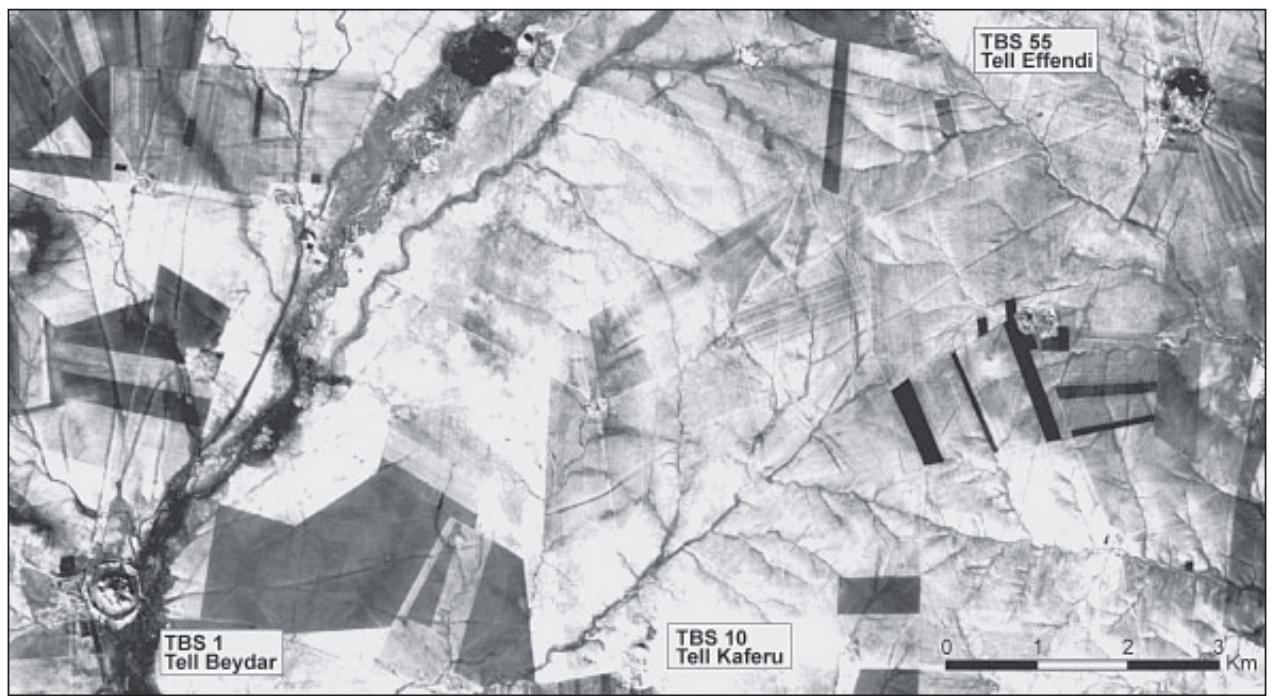

Figure 5. Dec. 1967 CORONA photograph showing hollow ways between the 3rd millennium BC towns of Tell Beydar, Tell Kaferu, and Tell Effendi.

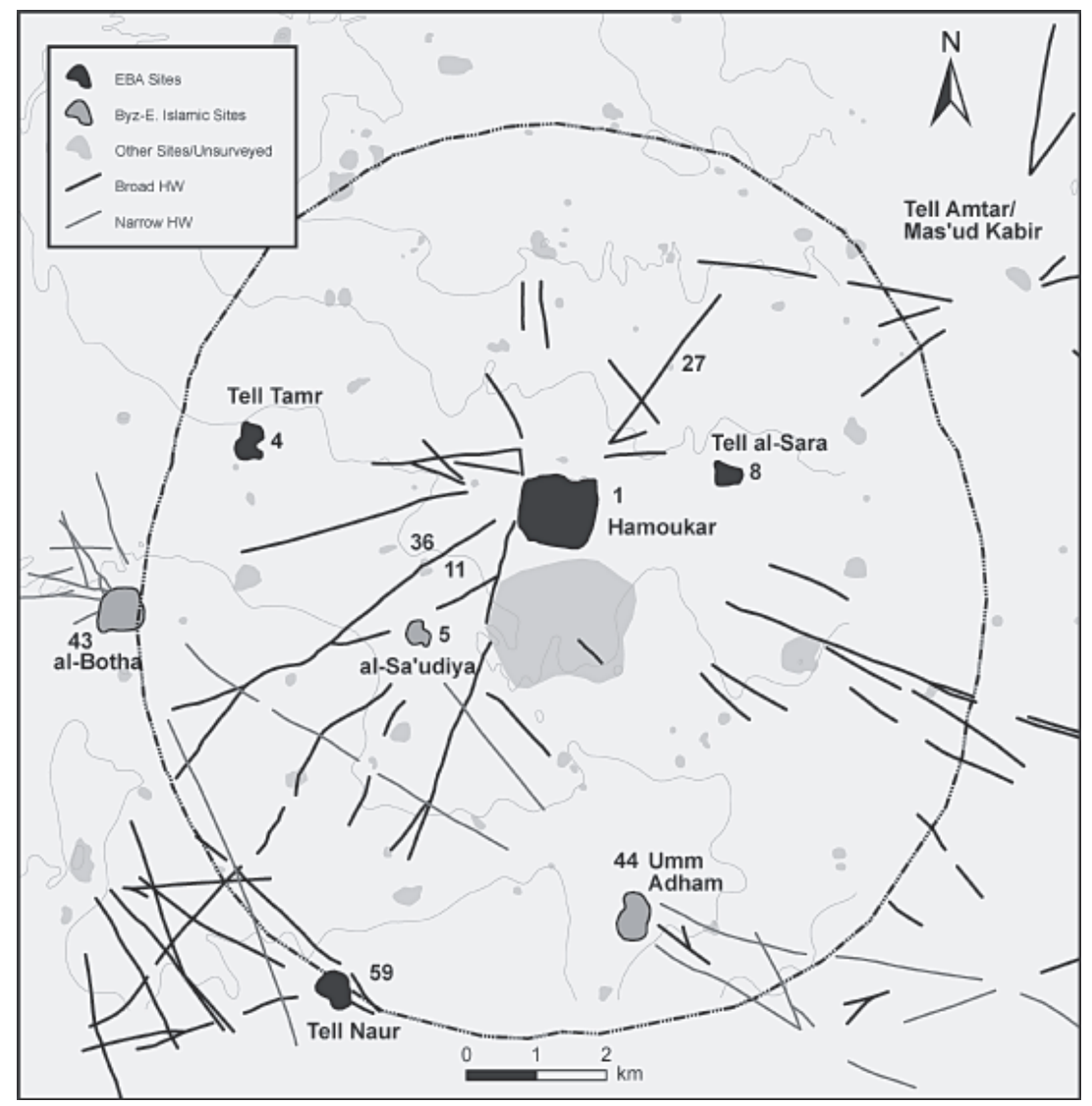

Figure 6. Broad (3rd millennium BC) and narrow (Byzantine-Early Islamic) hollow ways in the THS area. 
CORONA Satellite Photography and Ancient Road Networks: A Northern Mesopotamian Case Study

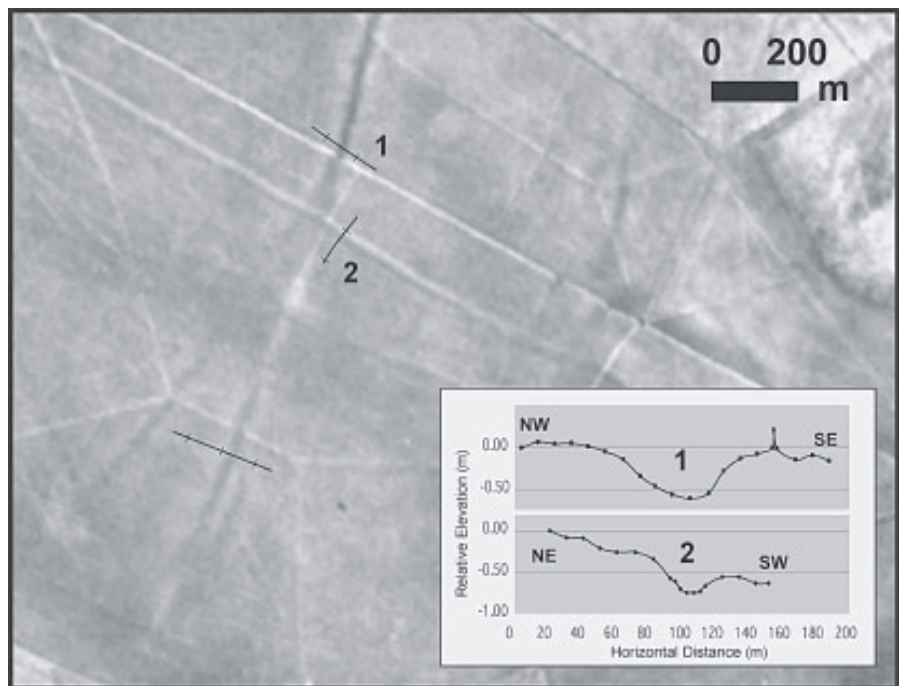

Figure 7. Dec. 1969 CORONA photograph (DS1108-1025DA006) showing a narrow hollow way cutting a broad hollow way $S W$ of Hamoukar; sections are vertically exaggerated.

\section{Local radial patterns around EBA sites}

As revealed by CORONA analysis, extensive radial systems are preserved around EBA tells (Figure 8). The maps of Van Liere and Lauffray under-represent the quantity of radial lines

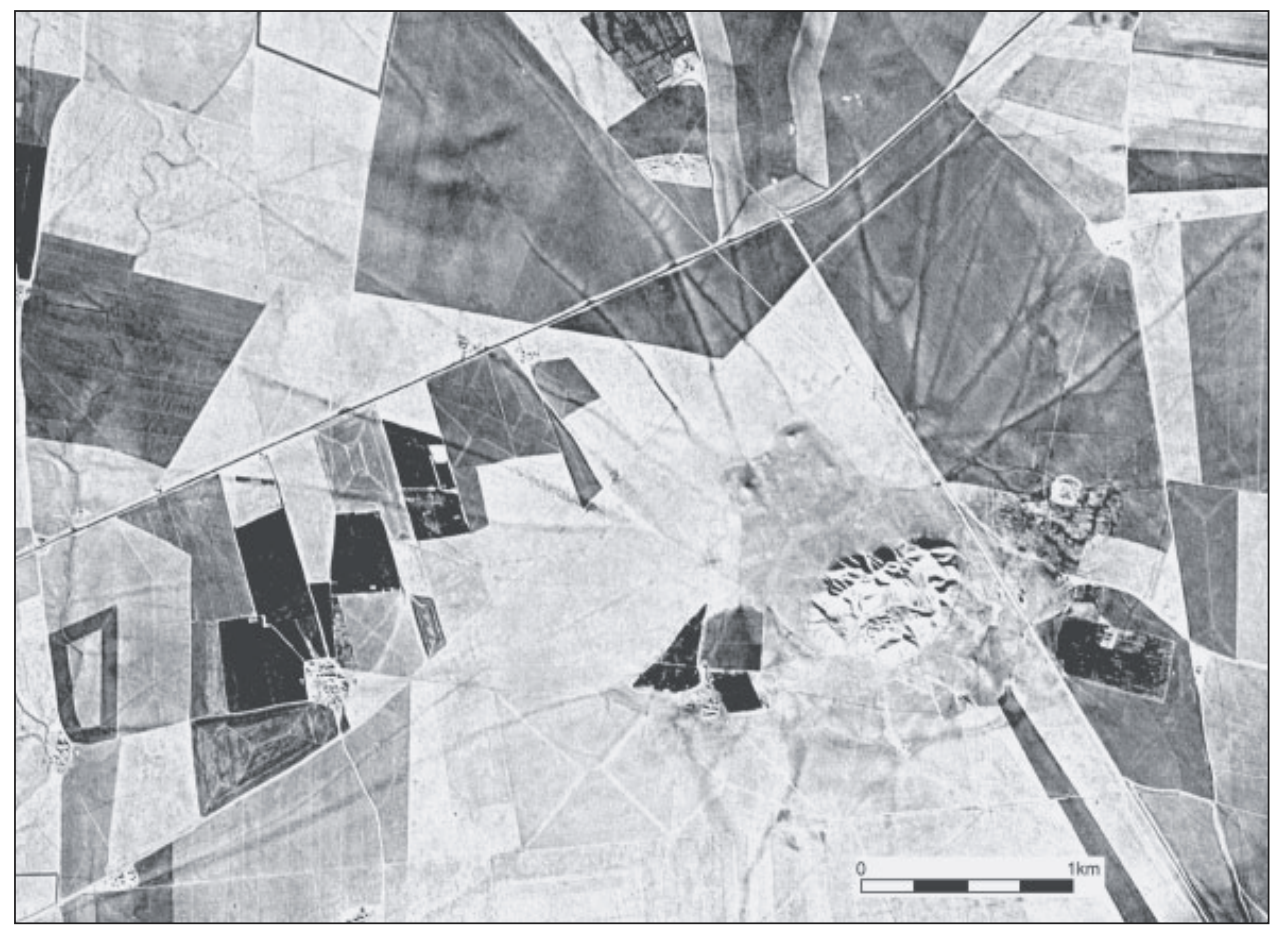

Figure 8. Nov. 1968 CORONA photograph (DS1105-1025DF058). Radial pattern of hollow ways around Tell Brak. 


\section{Jason $U r$}

Table 1. Comparison of quantity and aggregate length of hollow ways around major EBA sites as mapped by Van Liere and Lauffray and the CORONA-based reassessment.

\begin{tabular}{llcc}
\hline Site & No. of Hws & $\begin{array}{c}\text { Van Liere and } \\
\text { Lauffray 1954-55 }\end{array}$ & $\begin{array}{c}\text { CORONA-based } \\
\text { reassessment }\end{array}$ \\
\hline Hamoukar & Total Km & 10 & 33 \\
Beydar & No. of Hws & 57 & 49.4 (avg. $1497 \mathrm{~m}$ ) \\
& Total Km & 5 & 24 \\
Brak & No. of Hws & 29 & 30.3 (avg. $1262 \mathrm{~m}$ ) \\
Cholma Foqani & Total Km & 15 & 48 \\
& No. of Hws & 55 & 67.1 (avg. $1397 \mathrm{~m}$ ) \\
& Total Km & 7 & 26 \\
& & 23 & 45.9 (avg. $1767 \mathrm{~m}$ ) \\
\hline
\end{tabular}

around most sites as well as their lengths (Table 1). The reasons for this are uncertain, but may be related to the ground conditions at the time that they conducted their aerial survey. Another reason may be that they focused their efforts on the areas immediately around the most prominent tells and thus under-represented the landscape between sites.

The map of route systems in the western Upper Khabur basin depicts a very busy landscape (Figure 9). In surveyed areas, almost all EBA sites have at least one directly associated hollow way, and most have elaborate spoke-like systems which frequently interconnect and even overlap each other. The fading hollow ways should be understood as leading human traffic to

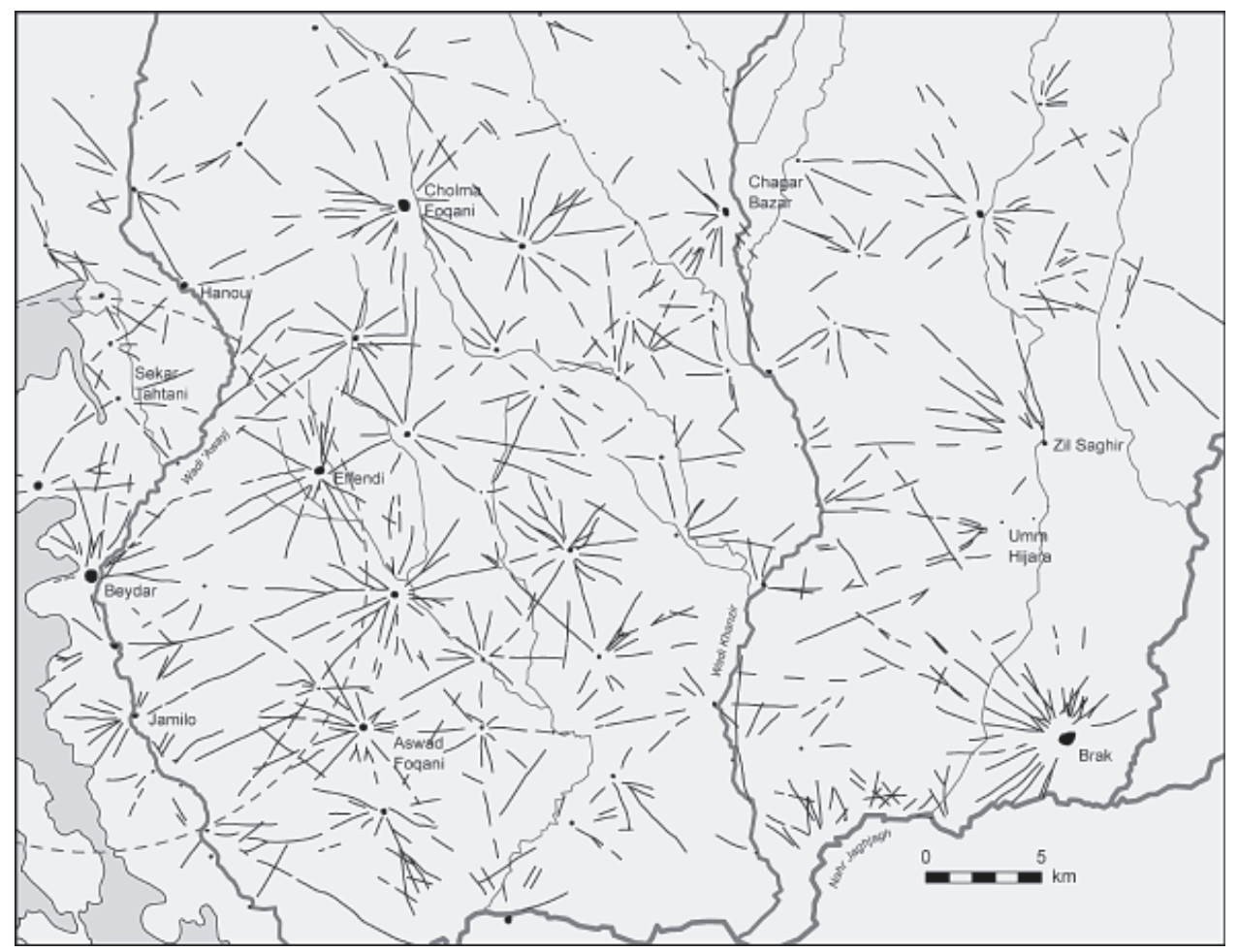

Figure 9. Hollow ways in the western Upper Khabur basin, with TBS survey area indicated. 
agricultural fields but the movement of flocks to pasture beyond the zone of cultivation was probably just as important, possibly more so for the formation of these features (Wilkinson and Tucker 1995: 27-28). This is certainly the case for the hollow ways leading west from the EBA sites along the Wadi 'Awayj south of Tell Beydar. In this area, a thin strip of arable land lies between the wadi and a basalt plateau covered by thin soils which probably served as an important pasture area (Courty 1994, Wilkinson 2000). The pastoral component of the Bronze Age economy has admittedly been under-represented (Wilkinson 1994: 515) although its importance has been well argued (Hole 1991, Kouchoukos 1998) direct archaeological traces of pastoralism remain ephemeral compared to agriculture.

Hollow way patterning in the eastern basin (Figure 10) is less dense, probably due to poorer conditions of preservation in three zones of aggradation. To the north, a higher annual rainfall than that of the western basin has probably resulted in local redepositing of erosional materials, possibly combined with the presence of a colluvial fan from the Tur Abdin mountains further north in Turkey. In the central basin, the floodplains of several wadis have left northsouth voids in the hollow way pattern. To the south, there is a large area of poor drainage along the lower reaches of these wadis. Although more fragmentary, the same pattern of radial systems around EBA tells can be detected in the windows of landscape preservation which appear between these zones.

\section{Intersite and regional routes}

Hollow ways connected sites over greater distances within the basin, to a greater degree than previously suspected. Rather than the isolated systems, the Upper Khabur pattern consists of

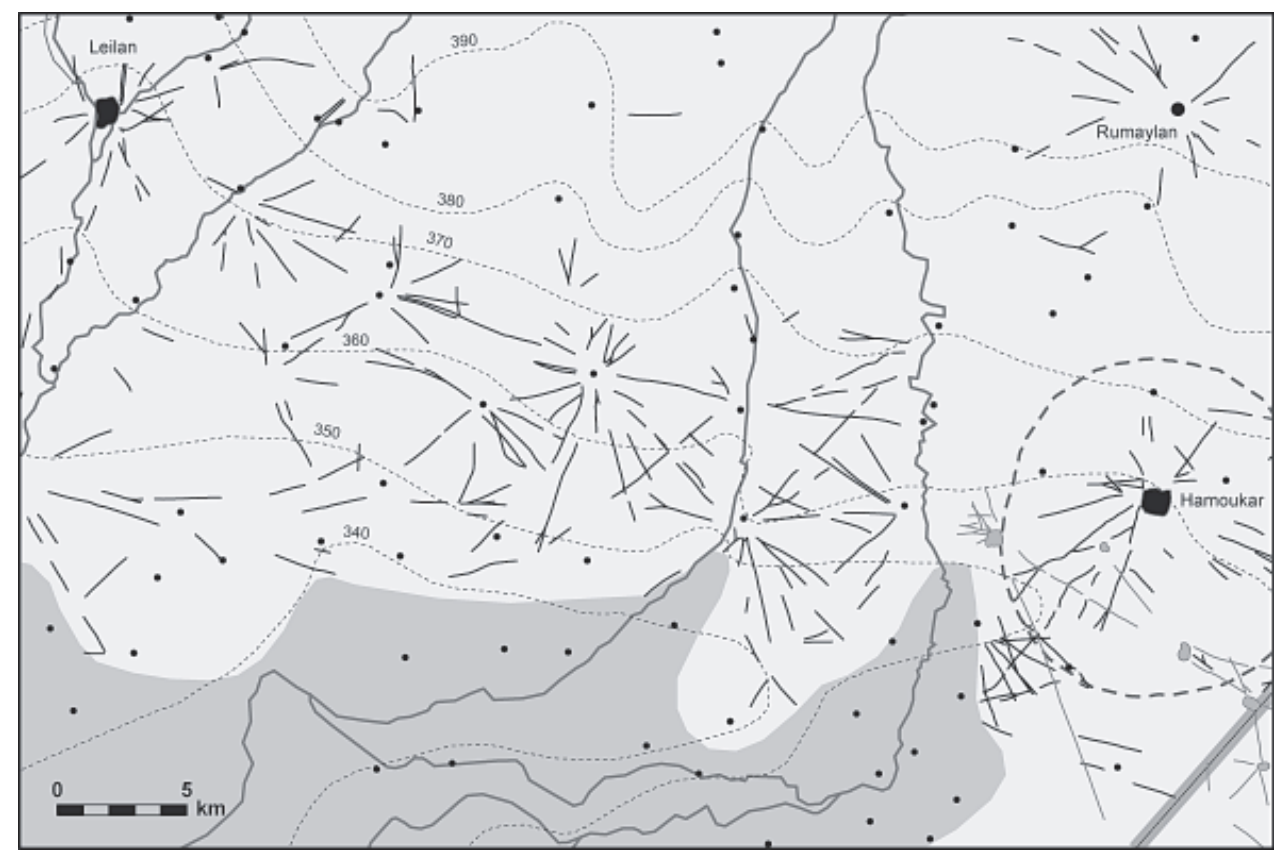

Figure 10. Hollow ways in the eastern Upper Khabur basin, with THS survey area indicated. 


\section{Jason Ur}

dozens of interconnecting networks. Although many hollow ways do appear to "fade out," presumably because they led into fields or pasture, a large quantity can be linked to other contemporary sites. For example, Tell Effendi (Figures 5 and 9) has a radial pattern of fifteen discrete hollow ways, and of these, seven can be linked to other tell sites, each with its own associated radial system.

These intersite routes are more than connections between towns and their immediate satellites; when considered at a regional level, these routes emerge as segments of larger "highways" running from site to site on a generally east-west axis. In the western basin, at least four major routes can be identified (Table 2, north to south).

In the eastern basin, the pattern is less complex: a single route connected the major urban centres at Tell Leilan and Tell Hamoukar, with gaps where wadi alluviation has deeply covered the ancient surface. Almost twenty kilometres of this route, out of the total $42.7 \mathrm{~km}$ distance, is preserved. Southeast of Hamoukar, this route connects with an interregional route which runs through Tell al-Samir and Tell Uwaynat toward Nineveh (Wilkinson and Tucker 1995: 26, 54, Figure 24 route E).

In both areas, a few regional routes on a north-south axis can be identified as well, but these are much less common. In the western basin, a series of discontinuous routes on a NWSE and N-S axis appear to be associated with Tell Brak. Rather than suggesting the dominance of east-west movement, this pattern probably resulted from the destruction of north-south routes by alluviation, as they probably would have followed the wadi floodplains.

For the Early Bronze Age, new conclusions can be drawn about the underlying economy, which had a large role in producing this pattern of settlements and roads. The agricultural underpinning of these towns (Weiss 1986, Wilkinson 1994) is vividly illustrated by the abundant radial systems of hollow ways, although the interconnectedness of these systems suggests a far more integrated agricultural economy than originally recognised. Given the transportation technology of the time, the regional routes were too long to have borne bulk commodities over their entire lengths; high value luxury items such as metals and textiles probably moved over these routes. The emerging textual record appears to support this reconstruction: administrative records from Brak, Beydar, and Ebla document trade in valuable animals and materials within and beyond the kingdom of Nagar (Tell Brak), which included Beydar as a dependency (Eidem et al. 2001).

Table 2. Major intersite routes in the western Upper Khabur basin. See Figure 11 for site locations.

\begin{tabular}{lcc}
\hline Route & Total Distance $(\mathbf{k m})$ & Preserved Hollow Ways $(\mathbf{k m})$ \\
\hline Tell Hanou to Chagar Bazar & 24.3 & 16.8 \\
Tell Sekar Tahtani to Tell Gir Zil Saghir & 40.1 & 19.4 \\
Tell Beydar to Tell Umm Hijara & 39.0 & 23.7 \\
Tell Jamilo to Tell Brak & 35.2 & 19.7 \\
\hline
\end{tabular}




\section{Reuse of hollow ways}

The remnants of ancient roads, in the form of hollow ways, were magnets for settlement in subsequent periods, not because of their transportation function but because of their unintended hydraulic function. In several places in the THS area, small LBA (Late Bronze Age) and Hellenistic settlements were located beside broad EBA hollow ways, which were slightly wider and deeper immediately adjacent to the sites (Figure 11). In these cases, the moisture-retaining troughs of the hollow ways were used as a source of material for mud bricks for the construction of the adjacent settlements. In this
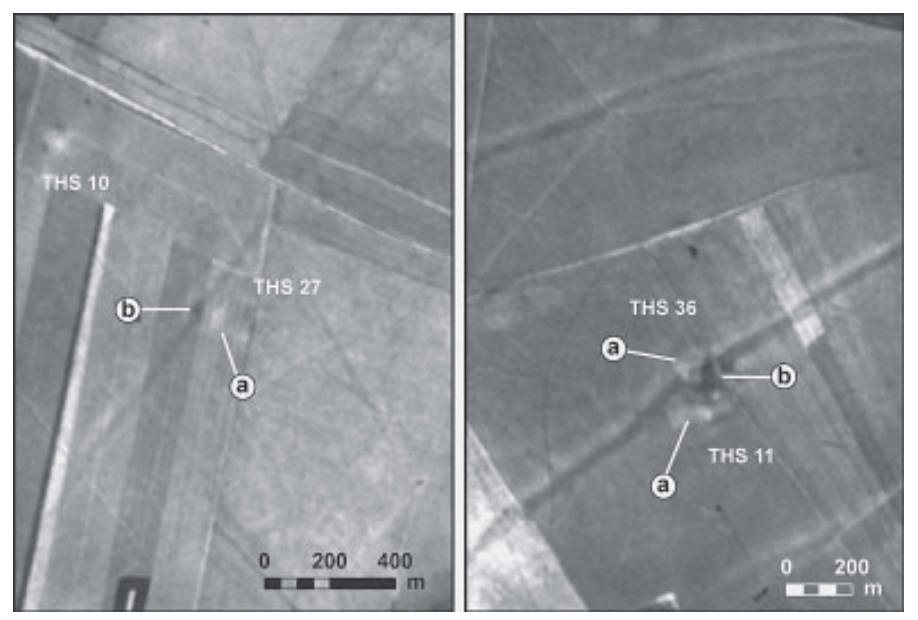

Figure 11. Reuse of hollow ways for brick material extraction in two areas near Hamoukar (DS1108-1025A005). a.) low mounded sites; b.) borrow pits. manner, the landscape impact of EBA urbanism influenced settlement location hundreds or thousands of years later.

\section{Summary and conclusions}

When aerial photography is limited or unavailable, as is the case in north-eastern Syria, CORONA photography can be a versatile tool for the identification of ancient sites and landscape features. Although they may prove to be less useful for wetter or more topographically complex areas, these photographs are a powerful data-source for identifying and locating sites and landscape features in semi-arid alluvial areas such as the plains of Northern Mesopotamia.

The dominant fact of life for the majority of the residents of these agricultural towns was their relationship with the land. If archaeologists wish to understand the organisational dynamics of early states, we must study the archaeological manifestations of this relationship. At the time of the formation of the first urban societies of northern Mesopotamia, human movement across the landscape was intense. It is not revolutionary to suggest that people and animals moved back and forth between fields, pastures, and settlements. However, we need not infer this movement; these actual pathways have left traces which are archaeologically recoverable. We can demonstrate the intensity of ancient movement and land use through a combination of fieldwork and remote sensing of hollow way patterns in the basin. The declassified CORONA satellite photographs have been instrumental in this undertaking. As modern human society continues on its current path of globalisation and industrialisation, the image of the landscape preserved by the CORONA mission will become an even more valuable resource for archaeological research. 


\section{Jason Ur}

\section{Note on access to CORONA}

Thumbnail images of individual CORONA photographs can be viewed online at http://edcsns17.cr.usgs.gov/ EarthExplorer/. Highly accurate SPOT images are available for download on the website of the US National Imagery and Mapping Agency.

\section{Acknowledgements}

This paper draws on fieldwork undertaken in north-eastern Syria in the context of two projects: the Tell Beydar Survey, led by Tony Wilkinson (part of the Syrian-European Tell Beydar Mission, directed by Marc Lebeau), and the Syrian-American Hamoukar Expedition, directed by McGuire Gibson and Amr al-Azm. I must thank all these directors for allowing me to participate. I am also grateful to the former and current Directors General of Antiquities and Museums in Damascus, Sultan Muhesen and Abd al-Razzak Moaz, as well as the Director of Excavations, Michel Maqdisi. Geoff Emberling, Augusta McMahon, and Gil Stein read early drafts; their comments are much appreciated. All errors are my own.

\section{References}

CourTy, M.A. 1994. Le cadre paléogéographique des occupations humaines dans le bassin du HautKhabur (Syrie du nord-est). Premiers résultats, Paléorient 20/1: 21-59.

Day, D., J. LogSDOn, \& B. LATELl (eds.). 1998. Eye in the sky: the story of the CORONA spy satellites. Washington and London: Smithsonian Institution.

Eidem, J., I. Finkel \& M. Bonechi. 2001. The third millennium inscriptions, in D. Oates et al. 2001: 99-120.

Hole, F. 1991. Middle Khabur settlement and agriculture in the Ninevite 5 period, Bulletin of the Canadian Society for Mesopotamian Studies 21: 1729.

Kennedy, D. 1998. Declassified satellite photographs and archaeology in the Middle East: case studies from Turkey, Antiquity 72: 553-61

Kouchoukos, N. 1998. Landscape and social change in late prehistoric Mesopotamia. Unpublished Ph.D. thesis, Department of Anthropology, Yale University.

Kouchoukos, N. 2002. Satellite images and Near Eastern landscapes, Near Eastern Archaeology 64: 80-91.

Mcclellan, T. \& A. Porter. 1995. Jawa and North Syria, Studies in the History and Archaeology of Jordan 5: 49-65.

Mcclellan, T., R. Grayson \& C. Ogleby. 2000. Bronze age water harvesting in North Syria, in O. Rouault \& M. Wäfler (eds.), La Djéziré et l'Euphrate Syriens de la protohistoire à la fin du IIe millénaire: 137-55. BREPOLS.

Oates, D., J. OAtes \& H. Mcdonald. 2001. Excavations at Tell Brak 2: Nagar in the third millennium BC. Cambridge: McDonald Institute for Archaeological Research.
Philip, G., D. Donoghue, A. Beck, \& N. Galiatsatos. 2002. CORONA satellite photography: an archaeological application from the Middle East, Antiquity 76: 109-18.

TAYLOR, C. 1979. Roads and tracks of Britain. London: Dent

TsOar, H. \& Y. YeKUTIELI. 1993. Geomorphological identification of ancient roads and paths on the loess of the northern Negev, Israel Journal of Earth Sciences 41: 209-16.

UR, J. 2002. Settlement and landscape in Northern Mesopotamia: the Tell Hamoukar Survey 1999_ 2001, Akkadica 123:57-88.

VAN Liere, W.J. 1963. Capitals and citadels of BronzeIron Age Syria in their relationship to land and water, Les Annales Archéologiques de Syrie 13: 109 22

VAN Liere, W.J. \& J. LaUfFray. 1954-55. Nouvelle prospection archéologique dans la haute Jezireh syrienne, Les Annales Archéologiques de Syrie 4-5: 129-48.

WeIss, H. 1986. The origins of Tell Leilan and the conquest of space in third millennium Mesopotamia, in H. Weiss (ed.), The origins of cities in dry-farming. Syria and Mesopotamia in the third millennium BC: 71-108. Guildford: Four Quarters.

Weiss, H. 1997. Leilan, IN H. Weiss (ed.), Archaeology in Syria, American Journal of Archaeology 101: 126-29.

Weiss, H. \& M.A. CourTy. 1994. Comment to Wilkinson 1994, Current Anthropology 35: $512-$ 14.

WiLKinson, T.J. 1993. Linear hollows in the Jazira, Upper Mesopotamia, Antiquity 67: 548-62.

WilKinson, T.J. 1994. The structure and dynamics of dry-farming states in Upper Mesopotamia, Current Anthropology 35: 483-520. 
CORONA Satellite Photography and Ancient Road Networks: A Northern Mesopotamian Case Study

WiLKInSON, T.J. 2000. Archaeological survey of the Tell Beydar region, Syria, 1997. A preliminary report, in K. Van Lerberghe \& G. Voet (eds.), Tell Beydar. Environmental and technical studies: $1-37$. Turnhaut: BREPOLS.
Wilkinson. T.J., C.A.I. French, W. Matthews, \& J. OATES. 2001. Geoarchaeology, landscape and the region, in D. Oates et al. 2001: 1-14.

Wilkinson, T.J. \& D. TuCKER. 1995. Settlement development in the North Jazira, Iraq. Warminster: Aris \& Phillips. 